\title{
The Legislative Dynamics of Political Decentralization in Parliamentary Democracies
}

\author{
Francesc Amat \\ University of Oxford $^{*}$ and Juan March Institute ${ }^{\dagger}$
}

Albert Falcó-Gimeno
University of Barcelona

This is a preprint (before peer-review process) of an article submitted for consideration in Comparative Political Studies. The final version of the article (which is different from this one) is forthcoming in 2014 in Comparative Political Studies.

\begin{abstract}
In this paper we investigate how particular configurations of national parliaments affect the dynamics of decentralization in parliamentary democracies. We contend that decentralization processes are endogenous to legislative bargaining by political parties. For that purpose we construct a new index of the Parliamentary Saliency for Decentralization (PSD) that reflects the distribution of parties' preferences for decentralization weighted by their legislative bargaining power. Recent research has emphasized the role of structural determinants of decentralization such as inter-regional inequality and ethno-linguistic diversity. However, we argue that the legislative bargaining by political parties is crucial to understand the dynamics of decentralization. Our main hypothesis is that -holding structural determinants constant- the greater the legislative bargaining power of parties with decentralization demands, the more likely decentralization reforms will occur. We test our hypotheses with dynamic models for 19 OECD parliamentary democracies by using Comparative Manifesto (CMP) data and the Regional Authority Index (RAI). We find evidence that, indeed, the dynamics of decentralization in parliamentary democracies are crucially shaped by legislative bargaining.
\end{abstract}

Keywords: Legislative bargaining; Decentralization; Political parties; Parliamentary Democracies.

\footnotetext{
* Nuffield College, University of Oxford, New Road, OX1 1NF, United Kingdom.

${ }^{\dagger}$ Center for Advanced Study in the Social Sciences, Juan March Institute, Castelló 77, 28006, Madrid, Spain.

‡ Department of Constitutional Law and Political Science, University of Barcelona, Diagonal 684, 08034 Barcelona, Spain.
} 


\section{Introduction}

When and why decentralization reforms take place in parliamentary democracies? This question can be understood as a particular reformulation of the well-known "who gets what, when, and how?” by Harold Lasswell (1936). This article provides an answer to the first question by focusing on how particular compositions of national parliaments affect decentralization reforms. What we mean by a particular configuration of the legislative is the distribution of seats among parties with different preferences for and against decentralization in a given legislature. By decentralization reforms we refer to changes in the distribution of political and fiscal authority between the central and the regional entities. In other words, we seek to provide an empirical test of the political mechanism that links the configuration of national parliaments with the adoption of decentralization reforms that increase (or decrease) regional authority.

Decentralization has been a widespread phenomenon in many countries over the last decades, and not only in developing countries but also in advanced democracies (Treisman 2007). However, many previous studies aimed at explaining decentralization levels and not decentralization dynamics (Beramendi 2007b, Treisman 2006, Erk and Koning 2010). Most of these works have emphasized the role of structural factors such as inter-regional inequality and ethno-linguistic diversity. But decentralization during the last 50 years has been a process whereby levels of authority of the subnational entities have been changing over time -in some countries in rather dramatic forms. Unfortunately, structural factors provide limited insight into such dynamic processes. Therefore, it is necessary to focus on particular institutional constraints and political incentives to provide more nuanced explanations for such dynamic processes. Our contribution here is to focus on the legislative politics associated with dynamic changes in decentralization. 
Simply put, our argument is that the composition of the legislative arena in parliamentary democracies is crucial to understand changes in the distribution of political authority between the centre and the regions. We argue that the specific distribution of political parties’ preferences and legislative bargaining power is a key determinant of dynamic changes in decentralization. By considering insights from both the legislative bargaining literature (Baron and Ferejohn 1989, Baron and Diermeier 2001) and the endogenous decentralization literature (Filippov et al. 2004, Beramendi 2012) we contend that in parliamentary democracies decentralization dynamics are endogenous processes subject to legislative bargaining by political parties.

Our contribution highlights the role of a specific institutional arena, namely the legislative, as the place in which political parties bargain and modify the distribution of political and fiscal authority. We argue that the actual distribution of political parties' preferences and bargaining power acts as an institutional constraint for the political will to modify how the centre and the regions share political authority. That is, we assume that any given party bargains in the legislative over decentralization subject to the distribution of preferences for decentralization and bargaining power of other parties. This is a rather obvious theoretical proposition that nonetheless has non-trivial empirical implications, namely the need to understand (and measure) the characteristics of legislative bargaining in parliamentary democracies in order to shed light on the nature of decentralization processes.

To test our hypotheses we construct an index of what we refer to as the degree of Parliamentary Saliency for Decentralization (PSD) that reflects the distribution of parties' preferences for decentralization weighted by their legislative bargaining power in each legislature. We collected data for 19 OECD parliamentary democracies over the period 19502006. To construct this index we use Comparative Manifesto (CMP) data that provides timevarying information about parties’ preferences regarding decentralization of political 
authority. On the other hand, we take advantage of the Regional Authority Index recently gathered by Hooghe et al. (2010) and therefore we conceptualize decentralization as a measure of the distribution of political power between the central and the regional authorities -which includes both fiscal and political competences.

\section{Theory: Mechanisms Behind the Dynamics of Decentralization}

\section{Endogenous Decentralization: Theoretical Perspectives}

There is a vast body of literature that uses decentralization as the main independent variable of interest to study its effects on all sorts of outcomes (Rodden and Wibbels 2002, Wibbels 2006). Over the recent years, though, many scholars have pointed out the need to endogenize decentralization and uncover its political determinants (Wibbels 2006, Beramendi 2007b). This effort is well justified as long as we are interested in claiming exogenous effects of decentralization. As Beramendi (2007b) highlights: "insofar as federal institutions reproduce the underlying tastes of the relevant political coalitions, they do not really matter per se”. ${ }^{1}$ In fact, this debate echoes an old remark formulated by Riker (1969): does federalism (and decentralization) have independent effects or it is rather an institutional outcome endogenous to the political preferences of the relevant political actors? If the latter is true then understanding the strategic incentives and institutional constraints under which the main political actors operate becomes essential.

The literature on endogenous decentralization has tended to focus on structural determinants, specially the empirical contributions (Panizza 1999, Treisman 2006, Erk and Koning 2010, Hooghe et al. 2008, 2010). Panizza (1999) highlighted the role of four main covariates associated with fiscal decentralization: land area, GDP per capita, ethnic

\footnotetext{
${ }^{1}$ The author refers to federal institutions but exactly the same logic applies when thinking about endogenous decentralization.
} 
fractionalization, and democratic history. On the other hand, Treisman (2006, 2007)

underscored the role of economic development, country size, and colonial history but did not find statistical evidence for ethnic diversity and democracy being associated with fiscal decentralization. However, the evidence provided by these studies is often times inconclusive, either because the sample of countries varies from one study to another or due to methodological concerns. And even more importantly, a common concern with these large- $\mathrm{N}$ cross-country empirical studies is the lack of attention to the political incentives and institutional constraints (Rodden 2004).

According to Hooghe et al. (2008), political authority of regional governments increased in most OECD countries between 1950 and 2006. Supply-side explanations of this gradual process of political decentralization are the absence of external threats, the global integration, pressures from international markets, and, last but not least, a functional logic of devolution intended to satisfy preference heterogeneity within countries (Erk and Swenden 2009). From a political-economy perspective, the works of Bolton and Roland (1997), Alesina and Spolaore (2003), and Beramendi (2007a) put the relation between distributive outcomes, inequality, and political and fiscal decentralization at the centre of the analysis. The main insight of this research is that understanding how the territorial distribution of income shapes individual preferences is fundamental to correctly account for the design of decentralized systems.

More recently, Erk and Koning (2010) have put forward a new structuralist approach for explaining institutional changes that takes into account the interaction between the social structure and the political mobilization of interest groups. They argue that in those heterogeneous countries with territorially concentrated linguistic groups -such as Spain or Belgium- political mobilization along linguistic lines should exert pressure for deepening fiscal decentralization. Conversely, in homogeneous federations without such political 
pressures, the tendency should be towards fiscal and institutional centralization. The approach by Erk and Koning (2010) is appealing but lacks a discussion of the institutional channels through which the demands of mobilized interest groups will be more or less successful. Even if it is true that structural factors are the main determinants of long-term institutional equilibriums, a study of the strategic incentives and institutional constraints is needed to account for the dynamics of decentralization.

Therefore, structural explanations of endogenous decentralization seem to be illequipped for providing an explanation that accounts for when and why decentralization reforms occur. Too often structural determinants have been assumed to work in a political vacuum when in fact decentralization is fundamentally a political outcome. Hence, the lack of a well-specified political mechanism becomes a hurdle to answer both the when and why questions. Instead, this paper conceives the process of decentralization in a parliamentary democracy as being endogenous to legislative bargaining by political parties. In other words, we contend that political incentives in a particular institutional scenario play a crucial role in explaining the dynamics of decentralization.

\section{The Role of Political Parties and Legislative Politics}

As said, we argue that it is necessary to bring politics back into the study of endogenous decentralization and go beyond structural explanations. In that sense, our approach is more related to the literature on the evolution of decentralization and party systems (Riker 1964, Chhibber and Kollman 2004, Brancati 2008, Swenden and Maddens 2009). This literature, however, is inconclusive with respect to the direction of causality linking party systems and decentralization. ${ }^{2}$ On the one hand, Chhibber and Kollman (2004) argue that it is the architecture of the state what drives the degree of party system

\footnotetext{
${ }^{2}$ See Amat et al. (2009) for a discussion of the relationship between the characteristics of the party system and the dynamics of decentralization.
} 
nationalization. One of their main insights is that regional parties will be more powerful the greater the degree of political authority at the subnational level. Similarly, Brancati (2008) has shown that the strength of regional parties increases with political decentralization.

On the other hand, and more in line with the argument presented here, Riker (1964) claimed that it is the structure of political parties what drives decentralization. Likewise, Filippov et al. (2004) argued that the stability of a federal contract is a function of a political conflict between political elites. They claim that the strategic incentives of electorally motivated political parties are the main source of stability in a given federation. If the structure of the party system is horizontally and vertically integrated institutions will be endogenously self-enforcing, whereas if electoral competition becomes fragmented territorial conflicts will emerge that will end up disrupting the core constitutional rules. Thus, the structure of the party system and electoral competition is the political mechanism that ultimately links the society’s composition with changes in institutional outcomes. Interestingly, recent studies like Lago-Peñas et al. (2009) and Beramendi (2012) have studied the relationship between the characteristics of the party system and the implementation of fiscal policies and decentralization of redistribution.

However, none of the studies on party systems and decentralization have focused on the specific institutional arenas in which political parties actually bargain to modify the distribution of political and fiscal authority at the regional level. That is the main reason why most of these works provide a political mechanism for why we should observe decentralization but still not a good reasoning about when those outcomes are likely to be implemented. In fact, studies like Caramani (2004) and Chhibber and Kollman (2004) undertake broad comparative historical approaches that highlight long-term trends in the evolution of party systems but at the cost of a more detailed analysis of the strategic incentives of political parties. Alternatively, Filippov et al. (2004) focus on parties’ strategic 
incentives but not on the actual institutional constraints that condition the ability of political parties to alter the rules of the game.

In this paper we argue that our understanding of when and why decentralization reforms are implemented can be improved by focusing on the distribution of seats among parties and their bargaining power in the legislature. In parliamentary democracies coalition and minority governments are the norm rather than the exception. As Müller and Strom (2000: 2-3) pointed out: “in the great majority of Western European states, coalition politics is at least an occasional occurrence, and often the order of the day”. But unfortunately, the literature on the political economy of decentralization has made extensive use of electoral competition models that assume unitary incumbents. ${ }^{3}$ However, in parliamentary democracies, coalition and minority governments reflect the preferences of more than one party (Baron and Diermeier 2001). This is because the confidence of a legislative majority is needed to sustain the executive government in place. Therefore policy outcomes like decentralization are the result of legislative bargaining among disciplined parties that form a legislative majority. In other words, the actual composition of the legislative becomes a key variable to understand when and why bills are passed.

Very much in line with this argument, Rodden and Wilkinson (2004) argue that in India the shift from an era of majoritarian dominance by the Congress Party towards a new scenario of coalition politics implied a change in the patterns of distributive politics. They present empirical evidence according to which a legislative bargaining model is helpful to understand the patterns of fiscal transfers in India during the post 1996 period. More recently, Rodden and Dragu (forthcoming) have analysed the role of territorial representation to explain levels of inter-regional redistribution across federations. They present a legislative bargaining model in which regional representatives form minimal winning coalitions and

\footnotetext{
${ }^{3}$ A reference that assumes a unitary incumbent which is very often used in the political economy literature on intergovernmental transfers is Dixit and Londregan (1996).
} 
decide over redistributive outcomes. However, the model they discuss is not appropriate for parliamentary democracies, where political parties are the main agenda-setters and act in a disciplined manner.

\section{Our Contribution and Empirical Implications}

In conclusion, legislative bargaining has received surprisingly little attention when studying the political determinants of decentralization -notwithstanding the recent efforts made by Rodden and Dragu (forthcoming). Given that decentralization is first and foremost a political outcome, one would expect legislative politics to play a relevant role in explaining the dynamics of decentralization. Beyond the importance of the vertical bargaining between national and subnational elites that previous research has emphasized, we claim that political bargaining over decentralization also takes place at the national level separately -namely, in national parliaments. At the end of the day it is within legislatures that political measures are decided upon. And this is particularly the case in parliamentary democracies.

We know that legislatures matter for policy outcomes. The formal theoretical study of bargaining within legislatures dates back to the seminal article of Baron and Ferejohn (1989). The implications of theirs and subsequent works in the same vein go mainly in two directions. First, the decision-making rules in the legislature (e.g. open vs. closed rules) provide more or less advantages for certain parties. Second, and more generally, the specific distribution of parties’ preferences and power make a huge difference to understand which will be the likely political outcomes in a given parliament (Axelrod 1970). The latter determines, among others, government formation. When one party alone gets the electoral votes necessary to reach the absolute majority of seats, the most likely formation is a single-party majority government where the party will be able to push policies towards her ideal point. By contrast, if no party beats the $50 \%$ seat share threshold then a coalition or a single-party minority cabinet has to 
form. That of course will influence the policies implemented depending on the preferences and power of each bargaining party.

The causal chain we defend, though, is one in which the configuration of parliaments is the key independent variable we should pay more attention to. Obviously, the executive will be the branch making policies, but in parliamentary democracies governments' policymaking and survival is inextricably linked to the confidence of the legislative. Therefore, the composition of the legislature is what determines government formation and, above all, how this government will operate and which policies will be allowed to pass. The main scenario giving birth to the actors that will eventually decide upon policies is, hence, the parliament. And decentralization policy is no exception. ${ }^{4}$

In sum, in this paper we claim that getting to know the specific configuration of the legislative arena will improve our understanding of when and why decentralization reforms are adopted. We thus expect legislative bargaining at the national level to account for a substantial part of unexplained variation in decentralization processes, notwithstanding all the structural determinants that have been said to explain decentralization outcomes -that is, keeping these factors constant.

First, everything else the same, we should expect a parliament preferring decentralization more intensely to be more likely to pass legislative reforms giving more power to regional entities. Second, we contend that the situation in which political parties find themselves to negotiate policies -namely, their legislative bargaining power- will be crucial to understand the dynamics of political decentralization. Even small changes in the

\footnotetext{
${ }^{4}$ As an illustration of this point, we could imagine a situation in which a two-party coalition cabinet has formed between a pro-centralization and a pro-decentralization party. If this coalition was surplus in the sense that the latter was unnecessary to guarantee the government's investiture and the former already held the absolute majority of seats, we would predict that the prospects for decentralization would be the same as if a former's single-party cabinet had formed. The key factor is thus the legislative configuration more than the executive's, and that applies regardless of the type of cabinet that is formed.
} 
distribution of forces within the legislature affecting the negotiation position of parties could greatly shift the prospects of decentralization reforms. This is why parties' bargaining power is the key variable determining parliaments’ salience for political decentralization.

To sum up, the main hypotheses to be tested in this article are the following: Hypothesis 1 (Legislative Bargaining Effect): An increase in the Parliamentary Salience for Decentralization (PSD) weighted by the legislative bargaining power induces a change in decentralization of political and fiscal powers from the central to the regional authorities.

Hypothesis 2 (Legislative Bargaining versus Alternative Measures): The measure of Parliamentary Salience for Decentralization (PSD) weighted by the legislative bargaining power outperforms both the absolute and the seat share weighted measures in explaining decentralization processes.

\section{Data and Variables}

For the empirical analyses we focus on 19 OECD parliamentary democracies over the time-period 1950-2006. By narrowing down our sample of countries and using cross-section time-series data we are able to test our hypotheses for a coherent set of countries and avoid common criticisms of previous empirical literature (Rodden 2004). Namely, we overcome the problems associated with large $\mathrm{N}$ cross-country studies by exploiting only within-country variation for a reduced number of countries for which we have well-defined theoretical expectations. The 19 countries under study are the following: Australia, Austria, Belgium, Canada, Denmark, Germany, Greece, Iceland, Ireland, Italy, Japan, Luxembourg, Netherlands, New Zealand, Norway, Spain, Sweden, Switzerland, and the United Kingdom. We gathered data coming from different sources. On the one hand we use the “Regional Authority Index (RAI)” by Hooghe et al. (2010) as our dependent variable 
(although we disaggregate its two main components in some analyses). On the other hand, we collected data from the Comparative Manifesto Project (for details see Budge et al. 2001) to construct our main independent variable of interest: the Parliamentary Salience for Decentralization (PSD). Other sources were used for the control variables.

\section{Dependent Variable: Political Decentralization}

Since our argument has mainly a political nature, namely focusing on legislative bargaining as a main political determinant of decentralization, we need to choose the measure of decentralization that fits best the specific purposes of our investigation (Stegarescu 2004). We are interested in a codification of decentralization that distinguishes the political power of central versus regional governments and at the same time qualifies the size and scope of regional authority. The former is crucial since our theoretical expectation is that parties with strong preferences for decentralization will bargain for an alteration of the status quo in the distribution of power between the centre and the regions. Also, we are interested in disentangling the nature of decentralization reforms. All in all, we believe that the data recently collected by Hooghe et al. (2010) constitutes the best index currently available for our purposes.

Hooghe et al. (2010) developed an index that measures regional authority in 42 developed democracies for the period 1950-2006. The "Regional Authority Index" (RAI) is an additive index of a variety of indicators that codify the extent to which regional authorities enjoy political power. Specifically, they define a regional government as "a coherent territorial entity situated between local and national levels with a capacity for authoritative decision making”. They conceive regional authority in two main scales that add up into a single index. On the one hand "Self-Rule" codifies the extent to which regional governments can make autonomous decisions over the citizens living in the region. On the other hand, "Shared-Rule” measures to what extent regional governments co-exercise authority with 
central governments. Each of these two main dimensions contains further indicators that describe various institutional arrangements. ${ }^{5}$ Hence, one of the advantages of the RAI index is the possibility to distinguish Self-Rule from Shared-Ruled when studying regional authority. Some of the analyses below are run separately for each dimension of RAI to study if legislative bargaining affects them differently.

The RAI index sums Self-Rule and Shared-Rule scores and ranges in a continuous scale from 1 to 24 . To illustrate the behaviour of RAI, Spain is an interesting country as it has experienced numerous decentralization reforms over the period 1978-2006. Spain scored 10 points in 1978 but reached 22.1 already in 1997. Looking at the RAI components, the main source behind this change was a dramatic increase in the Self-Rule of the Spanish Autonomous Communities, which climbed from 8.0 to 19.1 points during this period. The RAI index also increased significantly in many other countries in the sample. In Italy it grows from 8.5 to 22.7 between 1950 and 2006; in Belgium it rises from 14 points to 28.1 over the same years whereas in Ireland it goes from 0 to 6. Most of these increases followed gradual processes of decentralization reforms and most of them primarily affected the Self-Rule dimension of the RAI index.

It also bears mentioning that the RAI index behaves very coherently when compared to other decentralization measures widely used in previous literature (Arzaghi and Henderson 2005, Hooghe and Marks 2001, Land and Ersson 1999, Lijphart 1999, Treisman 2002, Woldendorp et al. 2000). Schakel (2008: 161) undertakes validity checks and conclude that "a comparison of the RAI with seven decentralization indices in the literature shows a great amount of agreement”. And more importantly, one of the main advantages of the RAI index is that compared to previous measures of decentralization it focuses on regional governments'

\footnotetext{
5 Self-Rule aggregates the following scales: institutional depth, policy scope, fiscal autonomy, and representation, while Shared-Rule aggregates law making, executive control, fiscal control, and constitutional reform. For a further description of each indicator see Hooghe et al. (2008).
} 
political authority and completely excludes local governments. Given that we are interested in how legislative bargaining affects the distribution of political authority between the centre and the regions, the RAI index is an appropriate measure of decentralization.

\section{Main Independent Variable: Parliamentary Salience for Decentralization (PSD)}

To repeat it again, in this paper we aim to test whether or not the specific configuration of legislatures has any effect on the timing of political decentralization reforms in a given country. Since decentralization reforms are mainly legislative outcomes, we argue that the preferences and bargaining strength of parties in the legislature should be important factors to understand the passage of this sort of laws, in addition to the more traditional structural determinants. To address this hypothesis empirically we first need to have a measure of how salient it is the issue of decentralization in any given legislature.

To do that, we used the CMP data (Budge et al. 2001) and picked the variables per301 and per302, which code parties’ claims regarding decentralization in several party documents. ${ }^{6}$ The former measures quasi-sentences with a positive feeling about decentralizing the political structure of the country, whereas the latter accounts for the opposite (namely, negative views over decentralization). Simply subtracting per302 from per301 gives us the overall stance of each party on decentralization. Since the observation level of the dependent variable is not the party, we needed to transform this information into a measure of how salient the issue of decentralization was for the parliament as a whole. The resulting variables were three different specifications of the Parliamentary Salience for Decentralization (PSD). ${ }^{7}$

First, we simply calculated the absolute (unweighted) average of the decentralization saliencies of the parties represented in Parliament which gives the Absolute Average PSD. Second, we weighted this average by the seat share of each party (Seat Share Weighted PSD).

\footnotetext{
${ }^{6}$ Though in a slightly different way, Benoit and Laver (2007) do also group per301 and per302 to account for the position of parties on the decentralization policy.

${ }^{7}$ Hereafter, PSD.
} 
Certainly, parliamentary parties do not have the same potential to make their demands successful in legislative terms. This is why relying on the unweighted measure alone can be misleading. However, we claim that the legislative negotiation potential of a party is best captured through its bargaining power rather than its mere seat share. This is why we calculated the Banzhaf power indices (Penrose 1946) of each party in the CMP database and used it as a weight for parties’ decentralization preferences. ${ }^{8}$ The resulting measure is our main independent variable: Bargaining Power Weighted PSD. Having the above three measures allows to compare the performance of the latter (which we believe is the one that should better predict changes in the decentralization policy) against the other two in order to know which is the added value of incorporating political parties' bargaining power in the analyses. The formula for the index measuring our main independent variable is the following:

$$
\text { Bargaining Power Weighted PSD } \mathrm{j}=\sum_{i=1}^{n}\left(\frac{b_{i}}{\sum_{i=1}^{n} b_{i}}\right) d_{i}
$$

Where $b$ reflects the Banzhaf index value of each party $i$ of the $n$ parties for which we had data in each legislature $j$, while $d$ captures the preference of party $i$ for or against decentralization (i.e. in CMP terms, per301-per 302). The temporal series of the variables Absolute Average PSD, Seat Share Weighted PSD, and Barg. Power Weighted PSD in our data are graphed by country in the following figure.

\section{[FIGURE 1 ABOUT HERE]}

\footnotetext{
${ }^{8}$ The Banzhaf power index is defined by the probability of changing an outcome of a vote where voting rights are not necessarily equally divided among the voters (parties, in our case). To calculate the voting power of each party, all winning coalitions must be listed and then critical parties must be counted (that is, a party who, if it changed its vote, would cause the measure to fail). A party's power is then measured as the fraction of all swing votes that it could cast.
} 
In general, this figure shows that the weighted variables present more variability than the unweighted one. This is not surprising since the latter captures, only, changes in political parties' preferences on the decentralization dimension from election to election. Instead, the weighted measures also incorporate political parties' strength to the picture. Hence, they have two sources of variation, which increase their variability. Interestingly, keeping the content of political parties’ manifestoes constant across elections, there could be a dramatic change in our bargaining power weighted index with a fairly minor change in the seat share distribution. For instance, a parliament with a pro-centralization party close to the absolute majority but falling behind it could take a much higher Barg. Power Weighted PSD value than in the exact same situation but with that party having reached the 50\% threshold (and that in principle could just be a matter of a couple of seats). In the latter case our measure would take exactly the value of the decentralization salience of that party. Spain provides again an interesting illustration of these differences.

\section{[FIGURE 2 ABOUT HERE]}

Although the three measures follow a similar general trend, the differences between them are also obvious. First, the absolute average is always above the other two, reflecting the presence of numerous regional parties (who want more decentralization) in the different Spanish Parliaments. Since in this measure their preferences weigh the same as those of larger parties, the value of the index is pushed upwards. Comparing the two weighted measures, it is fairly clear that the changes in the bargaining power-weighted measure are sharper than in the seat share one. The segments in which the former is highest coincide with periods where none of the main two state-wide parties ("Partido Socialista Obrero Español” (PSOE) and "Partido Popular” (PP)) controlled the absolute majority of seats (1993-1996, 1996-2000, 2004-2008). That makes sense as this is precisely when regional parties had more potential to influence parliamentary negotiations. 


\section{Controls}

As a first control, we include a variable capturing which is the social attitude towards decentralization. We do this by measuring the preferences for decentralization that the electorate showed in the last election. That is, which was the voting support received by the different partisan decentralization claims. The inclusion of the variable Electorate's Preferences for Decentralization is important because it allows isolating the effect of our main independent variable (namely, legislative bargaining power for decentralization, which is logically endogenous to election results) from the preferences of the electorate. Obviously, in the empirical analyses we also include control variables to account for structural determinants of decentralization (Panizza 1999; Erk and Koning 2010). These controls are GDP per capita, inter-regional inequality, ethno-linguistic fractionalization, area, and level of democracy at the country-level. The first two are time-varying variables whereas the last four are time-invariant. ${ }^{9}$ However, these controls are not incorporated in all the models.

The two time-varying controls are incorporated in some models only. The reason is that we have data for the whole time span both for the dependent variable and our main independent variable but not for all these controls. More specifically, for the inter-regional inequality control we use data on regional disparities recently gathered by Lessmann (2009). ${ }^{10}$ His study analyses the effect of fiscal decentralization on inter-regional inequalities for 23 OECD democracies from 1982 to 2000. Using data from Cambridge Econometrics, Lessmann (2009) develops several measures of inter-regional disparities. Here we use the coefficient of variation for regional income as our measure of Interregional Inequality. Controlling for regional disparities is crucial since previous research has highlighted a positive association between regional inequalities and decentralization of redistribution (Beramendi 2007a). There

\footnotetext{
${ }^{9}$ We treat our democracy level measure as an almost time-invariant control in our analyses.

${ }^{10}$ We thank Christian Lessmann for kindly making the data on inter-regional inequality available to us.
} 
is no data for five countries and several years. Hence, we opted for presenting the full sample models without the controls, while a reduced sample is used when time-varying controls are included.

Regarding the second time-varying control, both Panizza (1999) and Treisman (2006) provide evidence showing that economic development is associated with greater fiscal decentralization. To take this effect into account we include in our analyses the ( $\log$ of) GDP per Capita at constant 2000 US\$ based on data from the World Development Indicators.

As we shall see in the methodological section below, the most appropriate models given our data get rid of cross-country variability and, therefore, no time-invariant controls can be included. However, for robustness purposes, we run additional models in which their inclusion is possible. Specifically, we incorporate the Ethno-Linguistic Fractionalization measure by Roeder (2001) for the year 1985. Ethnic diversity has been argued to be a structural determinant of fiscal decentralization (Erk and Koning 2010) and others like Marks et al. (2008) have documented an "identity effect" according to which individuals "prefer rulers who share their ethno-cultural norms”. Admittedly, though, this measure is rather crude since it does not capture territorial concentration and the strength of regional identities. ${ }^{11}$ In addition, we include a measure of the ( $\log$ of) the Area of the country. Many previous studies on the origins of federalism and decentralization have highlighted country size as a structural determinant of decentralization (Panizza 1999; Erk and Swenden 2009). Marks et al. (2008) also find a "heteroskedasticity effect” according to which the variance in regional authority is greater in larger countries. The final (almost) time-invariant control is an institutional Democracy Indicator, which is an additive eleven-point scale (0-10) derived from codings of the competitiveness of political participation, the openness and competitiveness of executive recruitment, and constraints on the chief executive (Marshall et

\footnotetext{
${ }^{11}$ This is a common problem across the literature on endogenous decentralization (Panizza 1999; Beramendi 2007a; Erk and Koning 2010).
} 
al. 2010). Panizza (1999) provided evidence of a positive association between democracy and fiscal decentralization. Although our sample includes advanced parliamentary democracies only, there are still some differences across countries in the mentioned indicator. This is why we include it in some of the analyses.

Before turning to the methods section, we need to mention that the statistical analyses presented below are run in two differently structured datasets. The main analyses use a sample where legislatures are the observations. This obviously generated some problems to merge the different sources of data. The rule of thumb was to consider that the starting year of a legislature was the year after elections unless they were held before June $30^{\text {th }}$, in which case the election year and the legislature's starting year coincide. The final year followed the same "half-a-year” logic. The variables for which we had data on a country-year basis were averaged through the legislature's years except for the dependent variable, for which we were interested in the level of political decentralization that the parliament left at its dissolution. A second set of robustness analyses were run on a country-year sample, where the legislaturedependent variables (such as the CMP ones) where expanded to meet this structure using, again, the "half-a-year" rule of thumb. ${ }^{12}$

\section{Methods: Dynamic Models}

Our hypotheses refer to a dynamic political process and the data we count on has a time-series-cross-section (TSCS) structure. Accordingly, we use several dynamic models to estimate dynamic effects and in particular to identify how certain configurations of the legislative make changes in the legislation regarding political decentralization more or less likely and in which direction. To do this, we pursued a twofold identification strategy, one for the analyses of cross-legislatures' changes and another one taking yearly changes.

\footnotetext{
${ }^{12}$ For further details on this procedure, contact the authors.
} 


\section{Identification Strategy 1 (Legislatures)}

Since we want to estimate the effect of changes in our main independent variable on changes in our political decentralization index, we use first difference (FD) and ArellanoBond ( $\mathrm{AB}$ ) estimators. Given that our number of temporal observations is low (ranging from an average of 6.5 to 14.2 legislatures per country depending on the analysis), we make use of FD estimators to eliminate unit effects while avoiding bias in the estimations (Keele 2009).

$$
\Delta Y_{i, t}=\phi \Delta Y_{i, t-1}+\beta \Delta X_{i, t}+\Delta \mathrm{u}_{i, t}
$$

We also estimate AB models, which extend the FD model. Given that the differenced residuals $\Delta u_{i, t}$ are uncorrelated with all $Y_{i, t}$ and $X_{i, t}$ from $t-2$ to longer lag lengths, we have used the second lag as instrument for $\Delta Y_{i, t-1}$ in the equation above in our $\mathrm{AB}$ estimators.

\section{Identification Strategy 2 (Yearly)}

For robustness purposes, we also estimate Error Correction Models (ECM) as described in the equation below (Davidson et al. 1978). The main difference being that now the data has a country-year format instead of a legislature-based structure. ECM models are useful for two main purposes. First, ECM models are adequate for both stationary and nonstationary data. And second, ECM models are useful to distinguish the dynamics of the effects -immediate versus steady state impacts- and hence to describe the temporal adjustments of the dependent variable (Beck and Katz 2009). The coefficients for the lagged variables in levels reflect the persistent effects, whereas the coefficients for the differenced variables capture the transitory effects. Note that the parameter for the lagged dependent variable should be between -1 and 0 to ensure equilibrium properties.

$$
\Delta Y_{i, t}=\alpha+\beta \Delta X_{i, t}+\phi\left(Y_{i, t-1}-\gamma X_{i, t-1}\right)+u_{i, t}
$$


We estimate two types of ECM models. First, we run a standard ECM models using PCSE (Beck and Katz, 2009). We include both country and year dummies in order to account for unit effects and unobserved temporal shocks. Second, we include time-invariant controls by using the Fixed Effects Vector Decomposition method (FEVD) developed by Plümper and Troeger $(2004,2007)$. This procedure is helpful as it enables the inclusion of theoretically interesting controls that otherwise cannot be included and hence accounts for remaining unobserved heterogeneity. ${ }^{13}$ The FEVD algorithm proceeds in three steps. It first estimates the unit effects by a baseline FE model excluding the time-invariant variables, afterwards it regresses the unit effects on the time-invariant variables, and finally it re-estimates the first step by including both time varying and non-varying controls plus the residuals of the second step.

\section{Empirical Analyses}

Tables 1 and 2 display the estimates of the models predicting variations in the levels of the Regional Authority Index (RAI). The former presents data for nineteen countries while Table 2 loses five due to the inclusion of the economic controls. The main variable of interest in both tables is the Parliamentary Salience for Decentralization (PSD) measured in three different ways. The first-difference and Arellano-Bond estimators (FD and AB, respectively) show there is a relationship between the preferences of the parties in Parliament and actual political decentralization policy. However, the nature of this relationship depends on the measurement. Decentralization dynamics seem to respond, mainly, to changes in the bargaining power of parties claiming for more or less powers to the subnational entities.

\footnotetext{
${ }^{13}$ Note that Plümper et al (2007) argue that the FEVD is least biased estimator when time-variant and timeinvariant variables are correlated with the unit effects.
} 
In Table 1, a greater PSD produces more decentralization only if we weight the preferences of political parties by their legislative bargaining strength. By contrast, preferences alone do not seem to explain much: an increase in the (unweighted) average PSD appears to have no influence on decentralization (AB estimator) or even a counter-intuitive negative effect (FD estimator). Similarly, when party preferences are weighted by their seat share, decentralization dynamics seem to be unrelated to changes in the configuration of the Parliament. However, it is when bargaining power is taken into account when the partisan preferences in Parliament impact actual political decentralization.

[TABLE 1 ABOUT HERE]

[TABLE 2 ABOUT HERE]

In Table 2, where GDP per Cap. and Interregional Inequality are controlled for, the bargaining power weighted PSD continues to have the expected positive sign exerting a statistically significant influence on decentralization policy changes. Again, the other two measures perform worse, although the estimate of the seat share weighted PSD now reaches a 90\% level of statistical confidence. Read altogether, though, Tables 1 and 2 seem to suggest that the influence of political parties on decentralization is best captured through their bargaining power as defined by the Banzhaf index of voting power.

It is true that our main independent variable-Barg. Power Weighted PSD- has two elements: the salience of parties’ preferences and their bargaining power, at the same time. Hence, a change in the variable could reflect either a change in the preferences of a party in parliament holding bargaining power constant or vice versa. As explained above, we are mainly interested in estimating how bargaining power helps political parties translate their preferences into actual policies. To disentangle this effect from the mere preference one, what we have done is to compare this measure with the absolute and seat share weighted ones. Given that the bargaining power weighted measure appears to perform better than the other 
two (where preference change is also taken into account), we contend that bargaining power is crucial to understand how parties' platforms finally affect policy once in parliament.

Beyond the substantial independent variables, a brief mention of the control variables is also in order. Most notably, the preferences of the electorate regarding decentralization as measured through its voting behaviour increases the likelihood of decentralization policies in columns (1) only of Tables 1 and 2. However, when the weighted measures of PSD are included, the preferences of the electorate seem to be no longer relevant. Hence, controlling for which is the attitude of voters towards decentralization, the configuration of the parliament impacts how likely is the country to increase/decrease the level of decentralization. Note that the inclusion of the preferences of the electorate is important as it provides an argument against a possible critique of endogeneity. We take into account the preferences of the electorate and still we find an independent and remarkable legislative bargaining effect.

Similarly, the other two controls included in Table 2 have a statistically significant effect on the dependent variable, but in some specifications only. In columns (4) and (6) of Table 2, a higher GDP per capita makes the passage of decentralization reforms more likely, while countries where regions are more unequal in economic terms are less prone to undergo this kind of reforms. The latter result is intuitively reasonable since the higher the disparity between regions, the more likely the poorest ones would veto decentralization. This finding is in line with the evidence provided by some earlier studies (Ezcurra and Pascual 2008), although it runs counter to the implications of other works related to this issue. ${ }^{14}$ At any rate, these effects disappear when instead of Arellano-Bond estimators, we use First-Difference ones.

\footnotetext{
${ }^{14}$ Lessman (2009), for instance, finds that higher decentralization is associated to lower interregional inequalities. That would indirectly imply that there is no reason for poor regions to stand against decentralization.
} 
To increase our confidence in the statistical results provided above and check their robustness, we organized the data in a different way and repeated the analyses. While the observations in Tables 1 and 2 were each legislature in each country, in Table 3 the analyses are run in a dataset where each the observation is made in each year of the period analysed. The table reports the estimates of Error Correction Models (ECM) with panel-corrected standard errors (columns (1) and (3)) and with the Plümper-Troeger fixed effects vector decomposition three-step technique (columns (2) and (4)). Overall, the effect of changes in the PSD weighted by bargaining power seems to stand robustly across specifications. The coefficients have the expected positive sign and reach standard levels of statistical confidence. That suggests that an increase in the "power” of the PSD in parliament exerts a relevant short term or transitory effect the year after. However, as indicated by the lag of the variable (i.e. Barg. Power Weighted PSD (t-1)), the long-term effects do not resonate much and seem not to feed into subsequent years.

\section{[TABLE 3 ABOUT HERE]}

Apart from isolating short and long term effects, Table 3 also offers the fixed effects vector decomposition models, which make possible the inclusion of time-invariant and almost time-invariant controls. In one of the models we find that the more the ethno-linguistic fractionalization of a country, the more decentralization reforms or the deeper they are. However, neither the degree of “democraticness” nor the size of the country seems to affect our dependent variable. Lastly, the coefficient for the greek letter eta $(\eta)$ is statistically significant and with a value exactly equal to 1 (as it should be according to Plümper and Troeger (2004)).

Finally, Table 4 explores further the nature of our dependent variable by splitting its components. It presents the full models both taking legislatures and years as temporal observations. Clearly, the evidence found for the dependent variable RAI seems to follow 
what happens with one of its two main components: Self-Rule. Conversely, no systematic effect can be found for the other component: Shared-Rule. Therefore, it appears that changes in the configuration of the parliament in terms of parties' preferences and bargaining power condition the negotiation over which should be the degree of authority that the regional government ought to exercise over those who live in the region. However, questions such as which should be the regions' voice in the national institutions as a whole seem to be unaffected by parliamentary negotiations between political parties. This is an interesting finding. Whereas the intensity with which parties in parliament demand decentralization has an important effect on how likely it is the legislative passage of reforms giving regional governments more self-authority over the issues of the region, it does not have any impact on reforms giving regional authorities more influence on the country issues as a whole. This difference should certainly merit further attention in investigations to come.

\section{[TABLE 4 ABOUT HERE]}

Overall, we can conclude that our legislative bargaining weighted index of decentralization salience outperforms the unweighted average measure and the seat-share weighted one. The findings are well in line with the hypotheses posed above. Keeping all the traditional structural variables constant, there is an important additional political factor that determines the passage of decentralization reforms: the specific configuration of parties in parliament in terms of preferences and bargaining power. Hence, legislative bargaining does indeed seem to matter under the light of the evidence.

\section{Concluding Remarks}

In this paper we have shown that legislative bargaining crucially shapes the dynamics of decentralization in parliamentary democracies. More specifically, we have argued that the 
configuration of the national parliaments is a crucial determinant of changes in decentralization -something that has been largely overlooked in previous research (Treisman 2006, Erk and Koning 2010). The preferences of political parties for and against decentralization, along with their legislative bargaining power, are here said to be important factors behind the implementation of reforms devolving (or subtracting) power to (from) regional entities.

In order to test the hypotheses, we have used Hooghe et al.’s (2008) measures of political decentralization and merged them with information coming from CMP data to account for parties' positions regarding decentralization. We have constructed a new index of Parliamentary Salience for Decentralization (PSD) that reflects parties’ preferences weighted by their legislative bargaining power -using the Banzhaf voting power index. After incorporating controls for structural determinants, the analyses have shown that, indeed, changes in the composition of national parliaments actually translate into decentralization reforms. Parliaments with higher average decentralization salience are more prone to decentralize. But most importantly, the specific distribution of bargaining power among parties in parliament makes a dramatic difference in explaining the dynamics of decentralization. Thus, the focus on legislative bargaining places us in a much better position to answer when and why countries decentralize in parliamentary democracies.

All in all, we believe that future works willing to identify the political determinants of decentralization should direct their attention to parliaments and legislative politics. Here we have taken a step forward in this direction by looking at parties’ preferences and legislative bargaining power, but further efforts inquiring about other institutional characteristics of legislatures could certainly provide much insight in the study of countries' decentralization policies. All this new line of research follows, in fact, Riker's (1969) old advice arguing that in the study of federalism it is appropriate to focus on "the real forces in the political system". 
More generally, our approach shows that by taking into account the legislative bargaining power and the policy preferences of political parties it is possible to uncover the dynamics of policy change in parliamentary democracies. 


\section{References}

Alesina, A. and Spolaore, E. 2003. The Size of Nations. London: MIT Press.

Amat, F., Jurado, I. and León-Alfonso, S. 2009. “A Political Theory of Decentralization Dynamics”. Juan March Institute Working Paper Series \#248.

Arzaghi, M. and Henderson, V. 2005. "Why Countries are Fiscally Decentralizing”. Journal of Public Economics 89(7): 1157-89.

Axelrod, R. 1970. Conflict of Interest: A Theory of Divergent Goals with Applications to Politics. Chicago: Markham

Baron, D. and Ferejohn, J. 1989. "Bargaining in Legislatures”. American Political Science Review 83, 1181-1206.

Baron, D. and Diermeier, D. 2001. "Elections, Governments, and Parliaments in Proportional Representation Systems”. Quarterly Journal of Economics 116.

Beck, N. and Katz, J. 2009. "Modeling Dynamics in Time-Series-Cross-Section Political Economy Data”. California Institute of Technology, Social Science Working Paper 1304

Benoit, K. and Laver, M. 2007. "Estimating Party Policy Positions: Comparing Expert Surveys and Hand-Coded Content Analysis”. Electoral Studies 26: 90-107.

Beramendi, P. 2007a. "Inequality and the Territorial Fragmentation of Solidarity". International Organization 61: 783-820.

Beramendi, P. 2007b. "Federalism” in Carles Boix and Susan Stokes (eds.) Handbook of Comparative Politics. Oxford University Press.

Beramendi P. 2012. The Political Geography of Inequality: Regions and Redistribution. Cambridge University Press.

Brancati, D. 2008. “The Origins and Strength of Regional Parties”. British Journal of Political Science, 38(1): 135-159.

Bolton, P. and Roland, G. 1997. "The Breakup of Nations: a Political Economy Analysis.” Quarterly Journal of Economics 112: 1057-1090.

Budge, I., Klingeman, H.-D., Volkens, A., Bara, J., and Tanenbaum, E. 2001. Mapping Policy Preferences: Estimates for Parties, Electors and Governments 1945-1998. Oxford: Oxford University Press.

Chhibber, P. and Kollman, K. 2004. The Formation of National Party Systems: Federalism and Party Competition in Canada, Great Britain, India, and the United States. New Jersey: Princeton University Press. 
Caramani, D. 2004. The Nationalization of Politics. The Formation of National Electorates and Party Systems in Western Europe. Cambridge: Cambridge University Press.

Davidson, J., Hendry, D., Srba, F., and Yeo, S. 1978. "Econometric Modelling of the Aggregate Time-Series Relationship Between Consumers’ Expenditures and Income in the United Kingdom”. Economic Journal 88: 661-92.

Diermeier, D. nd Merlo, A. 2004. “An Empirical Investigation of Coalitional Bargaining Procedures”. Journal of Public Economics 88(3-4): 783-97.

Dixit, A. and Londregan, J. 1996. "The Determinants of Success of Special Interests in Redistributive Politics”. Journal of Politics 58, 4: 1132-55.

Dragu, T. and Rodden, J. 2010. "Representation and Regional Redistribution in Federations”. Documents de Treball IEB, n.16.

Enikolopov, R. and Zhuravskaya, E. 2007. "Decentralization and Political Institutions”. Journal of Public Economics, Vol 91, Issues 11-12, December 2007, Pages 22612290.

Erk, J. and Koning, E. 2010. "New Structuralism and Institutional Change: Federalism Between Centralization and Decentralization”. Comparative Political Studies.

Erk, J. and Swenden, W. (2009). "The New Wave of Federalism Studies", in Erk and Swenden (eds.) New Directions Federalism Studies. European Consortium for Political Research (ECPR) series. London: Routledge.

Ezcurra, R. and Pascual, P. 2008. "Fiscal Decentralization and Regional Disparities: Evidence From Several European Union Countries”. Environment and Planning A 40: 11851201.

Filippov, M., Ordeshook, P. and Shvetsova, O. 2004. Designing Federalism: a Theory of SelfSustainable Federal Institutions. Cambridge: Cambridge University Press.

Hooghe, L. and Marks, G. 2001. Multi-Level Governance and European Integration. Lanham, MD: Rowman \& Littlefield.

Hooghe, L. , Marks, G. and Schakel, A. 2008. "Regional Authority in 42 Democracies, 19502006: A Measure and Five Hypotheses”. Double Special Issue, Regional and Federal Studies, 18, 2-3: 111-302.

Hooghe, L., Marks, G. and Schakel, A. 2010. The Rise of Regional Authority: A Comparative Study of 42 Democracies (1950-2006). London: Routledge.

Keele, L. 2009. "Panel and TSCS Data Models”. Lecture Notes Manuscript. Ohio State University. 
Lago-Peñas, I. and Lago-Peñas, S. 2009. "Does the Nationalization of Party Systems Affect the Composition of Public Spending?”. Economics of Governance 10: 85-98.

Lane, J.-E. and Ersson, S. 1999. Politics and Society in Western Europe. London: Sage Publications.

Lasswell, H. 1936. Politics: Who Gets What, When, How. New York, London: McGraw-Hill. Laver, M. and Schofield, N. 1990. Multiparty government. Oxford: Oxford University Press.

Lessman, C. 2009. "Fiscal Decentralization and Regional Disparity: Evidence From CrossSection and Panel Data”. Environment and Planning A 41: 2455-2473.

Lijphart, A. 1999. Patterns of Democracy: Government Forms and Performance in Thirty-Six Countries. New Haven: Yale University Press.

Marks, G., Hooghe, L. and Schakel, A. 2008. "Patterns of Regional Authority”. Regional \& Federal Studies, 18(2): 167-181.

Marshall, M., Jaggers, K. and Gurr, T. 2010. “POLITY IV Project Codebook”.

Müller, W. and Strom, K. 2000. Coalition Governments in Western Europe. Oxford: Oxford University Press.

Panizza, U. 1999. “On the Determinants of Fiscal Centralisation: Theory and Evidence”. Journal of Public Economics 74(1).

Plümper, T. and Troeger, V. 2007. "Efficient Estimation of Time-Invariant and Rarely Changing Variables in Panel Data Analysis with Unit Effects”. Political Analysis 15(2): 124-139.

Riker, W.H. 1964. Federalism: Origin, Operation, Significance. Boston: Little Brown and Co.

Riker, W. H. 1969. "Six Books in Search of a Subject or Does Federalism Exist and Does It Matter?”. Comparative Politics, Vol.2.

Rodden, J. 2002. "Strength in Numbers? Representation and Redistribution in the European Union.” European Union Politics 3, 2: 151-175.

Rodden, J. and Wibbels, E. 2002. "Beyond the Fiction of Federalism: Macroeconomic Management in Multitiered Systems”. World Politics - Volume 54, Number 4, pp. 494-531.

Rodden, J. 2004. "Comparative Federalism and Decentralization: On Meaning and Measurment”. Comparative Politics 36,4: 481-500.

Rodden, J. and Dragu, T. Forthcoming. "Representation and Redistribution in Federations”. Proceedings of the National Academy of Sciences.

Rodden, J. and Wilkinson, S. 2004. "The Shifting Political Economy of Redistribution in the Indian Federation”. Unpublished Manuscript. 
Roeder, P. G. 2001. "Ethnolinguistic Fractionalization (ELF) Indices, 1961 and 1985”. http//:weber. ucsd.edu/ proeder/elf.htm.

Schakel, A. H. 2008. "Validation of the Regional Authority Index". Regional and Federal Studies 18 (2-3): 143-166.

Stegarescu, D. 2004. "Public Sector Decentralization: Measurement Concepts and Recent International Trends”. ZEW Discussion Paper No. 04-74.

Swenden, W. and Maddens, B. 2008. Territorial Party Politics in Western Europe. Basingstoke: Palgrave Macmillan.

Treisman, D. 2002. "Defining and Measuring Decentralization: A Global Perspective." Manuscript.

Treisman, D. 2006. "Explaining fiscal decentralization: geography, colonial history, economic development and political institutions”. Journal of Commonwealth and Comparative Politics 44:3.

Treisman, D. 2007. The Architecture of Government: Rethinking Political Decentralization. Cambridge University Press, Cambridge, UK.

Wibbels, E. 2006. "Madison in Baghdad? Decentralization and federalism in Comparative Politics”. Annual Review of Political Science 9: 165-188.

Woldendorp, J., Keman, H., and Budge, I. 2000. Party Government in 28 Democracies (19451998): Composition - Duration - Personnel. Dordrecht: Kluwer Academic Publishers. 


\section{Figures}

\section{Figure 1}

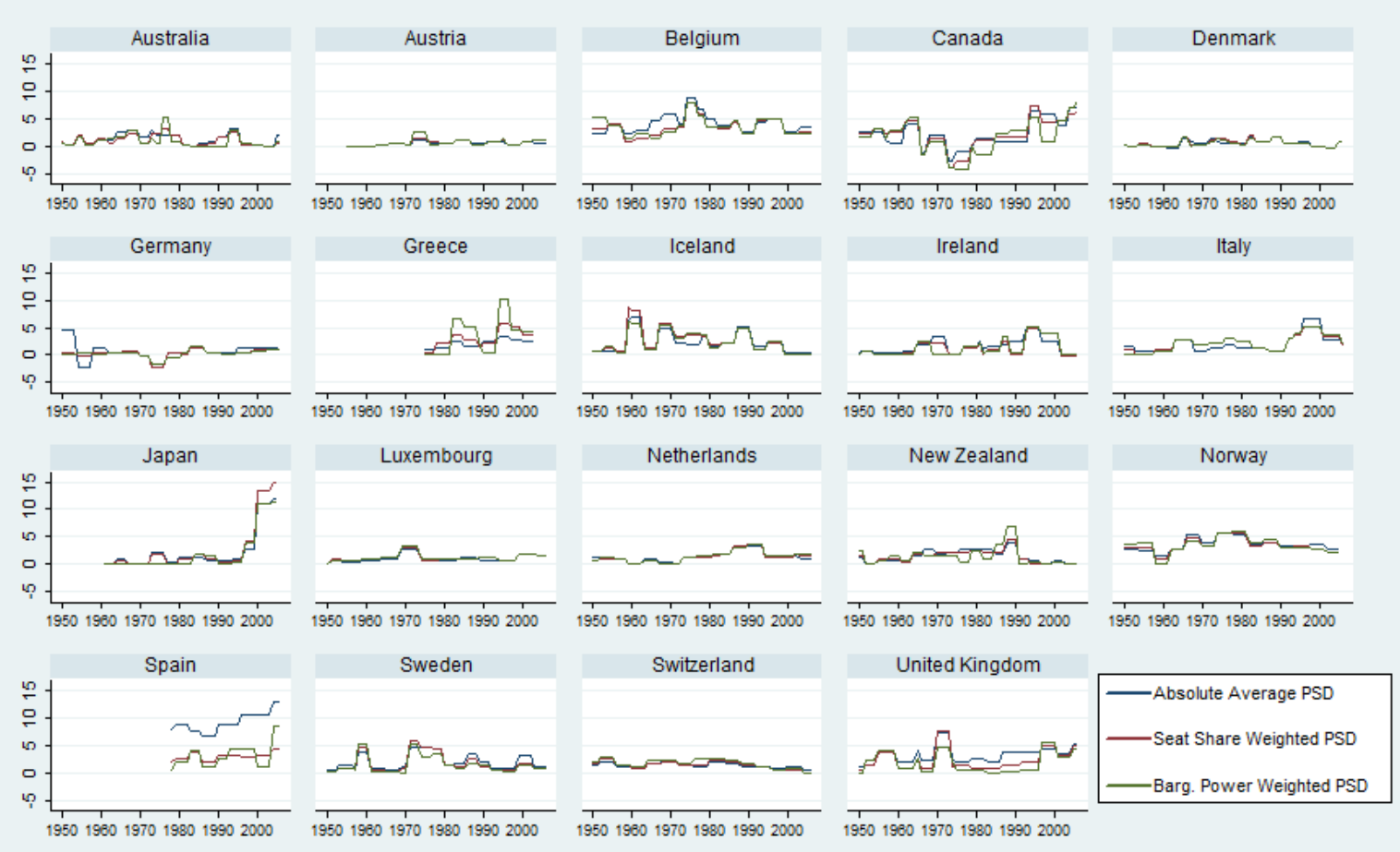

\section{Figure 2}

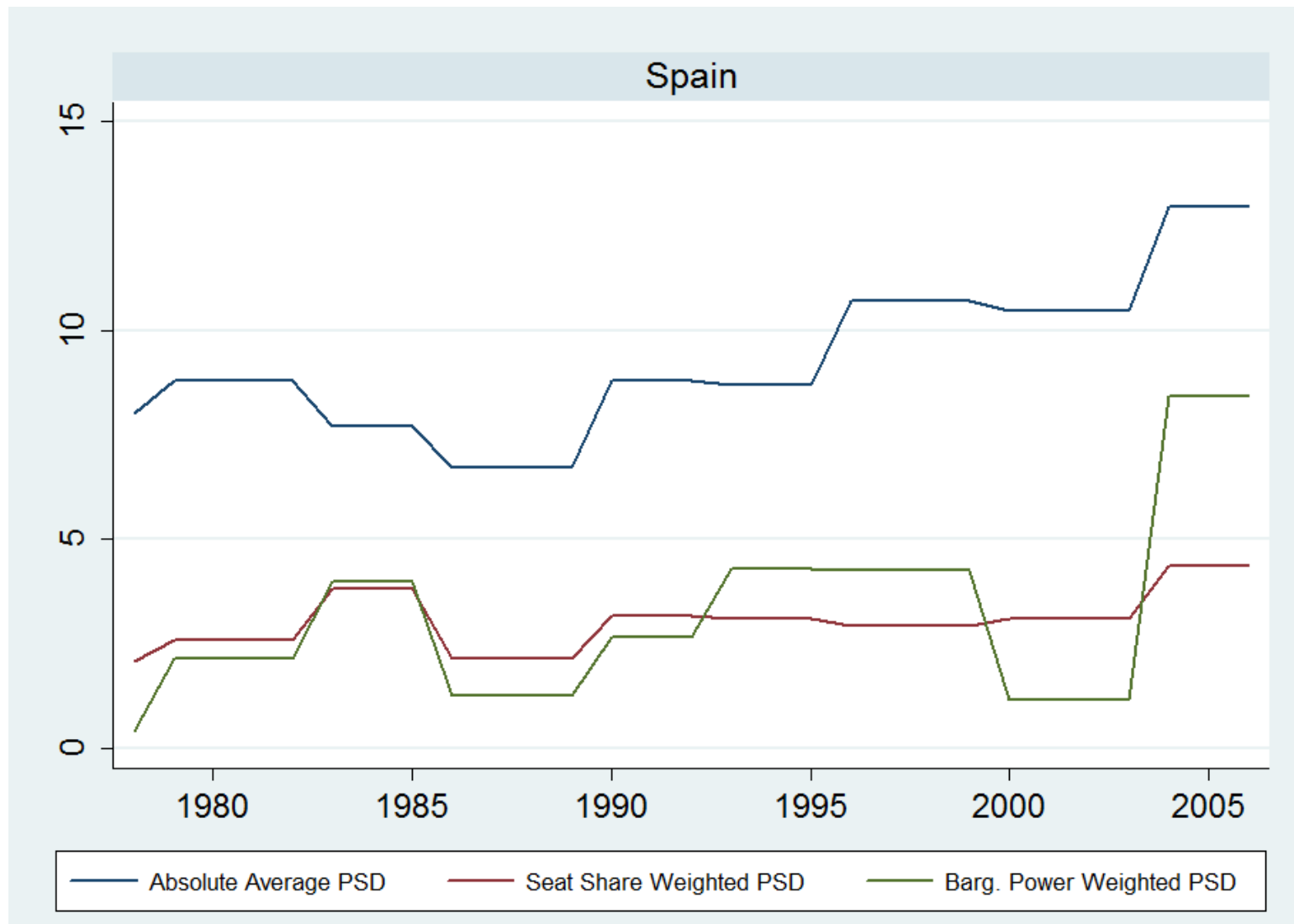


Tables

Table 1

\begin{tabular}{|c|c|c|c|c|c|c|}
\hline & $\begin{array}{l}\text { FD } \\
(1)\end{array}$ & $\begin{array}{l}\mathrm{AB} \\
(2)\end{array}$ & $\begin{array}{l}\text { FD } \\
(3)\end{array}$ & $\begin{array}{l}\mathrm{AB} \\
(4)\end{array}$ & $\begin{array}{l}\text { FD } \\
(5)\end{array}$ & $\begin{array}{l}\mathrm{AB} \\
(6)\end{array}$ \\
\hline $\operatorname{RAI}\left(\Delta_{\mathrm{t}-1} / \mathrm{t}-1\right)$ & $\begin{array}{l}-0.011 \\
(0.057)\end{array}$ & $\begin{array}{c}0.775^{* * *} \\
(0.094)\end{array}$ & $\begin{array}{c}0.021 \\
(0.057)\end{array}$ & $\begin{array}{c}0.817 * * * \\
(0.086)\end{array}$ & $\begin{array}{c}0.032 \\
(0.057)\end{array}$ & $\begin{array}{c}0.826 * * * \\
(0.104)\end{array}$ \\
\hline Absolute Average PSD $(\Delta / \mathrm{t})$ & $\begin{array}{c}-0.284^{* *} \\
(0.116)\end{array}$ & $\begin{array}{c}0.157 \\
(0.536)\end{array}$ & & & & \\
\hline Seat Share Weighted PSD $(\Delta / \mathrm{t})$ & & & $\begin{array}{c}0.241 \\
(0.264)\end{array}$ & $\begin{array}{c}1.237 \\
(1.174)\end{array}$ & & \\
\hline Barg. Power Weighted PSD $(\Delta / \mathrm{t})$ & & & & & $\begin{array}{c}0.128 * * \\
(0.060)\end{array}$ & $\begin{array}{l}0.227 * \\
(0.127)\end{array}$ \\
\hline $\begin{array}{l}\text { Electorate's Pref. for Decentralization } \\
(\Delta / t)\end{array}$ & $\begin{array}{c}0.314 * * * \\
(0.109)\end{array}$ & $\begin{array}{l}-0.078 \\
(0.663)\end{array}$ & $\begin{array}{l}-0.183 \\
(0.279)\end{array}$ & $\begin{array}{l}-1.210 \\
(1.253)\end{array}$ & $\begin{array}{l}-0.054 \\
(0.071)\end{array}$ & $\begin{array}{l}-0.163 \\
(0.116)\end{array}$ \\
\hline Constant & $\begin{array}{l}0.272 * * * \\
(0.077)\end{array}$ & & $\begin{array}{c}0.253 * * * \\
(0.077)\end{array}$ & & $\begin{array}{c}0.247 * * * \\
(0.077)\end{array}$ & \\
\hline $\mathrm{F}(3,265$ / 2,18) & $2.89 * *$ & $39.31 * * *$ & 1.16 & $34.62 * * *$ & $2.43^{*}$ & $22.23^{* * *}$ \\
\hline $\mathrm{AB}$ test or $\mathrm{AR}(1) \mathrm{Z}$ & & $-2.10 * *$ & & $-2.30 * *$ & & $-2.19 * *$ \\
\hline $\mathrm{AB}$ test or $\mathrm{AR}(2) \mathrm{Z}$ & & -1.03 & & -0.75 & & -0.94 \\
\hline Observations & \multicolumn{6}{|c|}{269} \\
\hline Number of countries & \multicolumn{6}{|c|}{19} \\
\hline
\end{tabular}

Standard errors in parentheses

*** $\mathrm{p}<0.01,{ }^{* *} \mathrm{p}<0.05,{ }^{*} \mathrm{p}<0.1$

Table 2

\begin{tabular}{|c|c|c|c|c|c|c|}
\hline & $\begin{array}{l}\text { FD } \\
(1)\end{array}$ & $\begin{array}{l}\mathrm{AB} \\
(2)\end{array}$ & $\begin{array}{l}\text { FD } \\
(3)\end{array}$ & $\begin{array}{l}\mathrm{AB} \\
(4) \\
\end{array}$ & $\begin{array}{l}\text { FD } \\
(5)\end{array}$ & $\begin{array}{l}\mathrm{AB} \\
(6) \\
\end{array}$ \\
\hline $\operatorname{RAI}\left(\Delta_{\mathrm{t}-1} / \mathrm{t}-1\right)$ & $\begin{array}{c}-0.050 \\
(0.088)\end{array}$ & $\begin{array}{c}0.230 \\
(0.147)\end{array}$ & $\begin{array}{c}0.010 \\
(0.090)\end{array}$ & $\begin{array}{c}0.165 \\
(0.137)\end{array}$ & $\begin{array}{c}0.050 \\
(0.091)\end{array}$ & $\begin{array}{l}0.238 * * \\
(0.080)\end{array}$ \\
\hline Absolute Average PSD $(\Delta / \mathrm{t})$ & $\begin{array}{c}-0.610^{* * *} \\
(0.182)\end{array}$ & $\begin{array}{c}-0.229 \\
(0.256)\end{array}$ & & & & \\
\hline Seat Share Weighted PSD $(\Delta / \mathrm{t})$ & & & $\begin{array}{l}1.173^{*} \\
(0.643)\end{array}$ & $\begin{array}{l}2.690 * \\
(1.425)\end{array}$ & & \\
\hline Barg. Power Weighted PSD $(\Delta / \mathrm{t})$ & & & & & $\begin{array}{c}0.235 * * \\
(0.096)\end{array}$ & $\begin{array}{l}0.230^{*} \\
(0.112)\end{array}$ \\
\hline $\begin{array}{l}\text { Electorate's Pref. for Decentralization } \\
\left(\Delta / t_{t}\right)\end{array}$ & $\begin{array}{c}0.786^{* * *} \\
(0.187)\end{array}$ & $\begin{array}{c}0.416 \\
(0.393)\end{array}$ & $\begin{array}{l}-1.009 \\
(0.711)\end{array}$ & $\begin{array}{r}-2.707^{*} \\
(1.415)\end{array}$ & $\begin{array}{l}-0.009 \\
(0.160)\end{array}$ & $\begin{array}{l}-0.033 \\
(0.245)\end{array}$ \\
\hline Interregional Inequality $(\Delta / \mathrm{t})$ & $\begin{array}{l}-8.381 \\
(8.312)\end{array}$ & $\begin{array}{c}-5.584 \\
(5.397)\end{array}$ & $\begin{array}{c}-10.719 \\
(8.680)\end{array}$ & $\begin{array}{c}-12.087 * * \\
(4.731)\end{array}$ & $\begin{array}{c}-11.687 \\
(8.576)\end{array}$ & $\begin{array}{c}-16.971^{* *} \\
(7.295)\end{array}$ \\
\hline (Log of) GDP per Cap. $(\Delta / \mathrm{t})$ & $\begin{array}{c}3.595 \\
(2.894)\end{array}$ & $\begin{array}{c}2.956 \\
(2.503)\end{array}$ & $\begin{array}{c}4.028 \\
(3.020)\end{array}$ & $\begin{array}{l}3.491^{*} \\
(1.877)\end{array}$ & $\begin{array}{c}4.714 \\
(2.996)\end{array}$ & $\begin{array}{l}3.206^{*} \\
(1.546)\end{array}$ \\
\hline Constant & $\begin{array}{c}0.173 \\
(0.249)\end{array}$ & & $\begin{array}{c}0.088 \\
(0.259)\end{array}$ & & $\begin{array}{c}0.002 \\
(0.259)\end{array}$ & \\
\hline $\mathrm{F}(5,85 / 4,13)$ & $3.89 * * *$ & 0.79 & $2.17 *$ & 2.00 & $2.74 * *$ & $4.85 * * *$ \\
\hline $\mathrm{AB}$ test or $\mathrm{AR}(1) \mathrm{Z}$ & & -1.33 & & -1.33 & & -1.55 \\
\hline $\mathrm{AB}$ test or $\mathrm{AR}(2) \mathrm{Z}$ & & -0.70 & & -0.48 & & -0.83 \\
\hline Observations & & & & 91 & & \\
\hline Number of countries & & & & 14 & & \\
\hline
\end{tabular}


Table 3

\begin{tabular}{|c|c|c|c|c|}
\hline & $\begin{array}{c}\text { PCSE } \\
(1)\end{array}$ & $\begin{array}{l}\text { FEVD } \\
(2)\end{array}$ & $\begin{array}{c}\text { PCSE } \\
(3)\end{array}$ & $\begin{array}{l}\text { FEVD } \\
(4)\end{array}$ \\
\hline $\operatorname{RAI}(\mathrm{t}-1)$ & $\begin{array}{c}-0.051 * * * \\
(0.016)\end{array}$ & $\begin{array}{c}-0.079 * * * \\
(0.019)\end{array}$ & $\begin{array}{c}-0.142 * * * \\
(0.049)\end{array}$ & $\begin{array}{l}-0.181 \\
(0.170)\end{array}$ \\
\hline Barg. Power Weighted PSD $(\Delta)$ & $\begin{array}{c}0.110^{* *} \\
(0.043)\end{array}$ & $\begin{array}{c}0.122 * * * \\
(0.044)\end{array}$ & $\begin{array}{c}0.206 * * * \\
(0.070)\end{array}$ & $\begin{array}{c}0.222^{* * *} \\
(0.073)\end{array}$ \\
\hline Barg. Power Weighted PSD ( $\mathrm{t}-1)$ & $\begin{array}{c}0.048 \\
(0.034)\end{array}$ & $\begin{array}{c}0.050 \\
(0.037)\end{array}$ & $\begin{array}{c}0.074 \\
(0.060)\end{array}$ & $\begin{array}{c}0.068 \\
(0.085)\end{array}$ \\
\hline $\begin{array}{l}\text { Electorate's Pref. for Decentralization } \\
(\Delta)\end{array}$ & $\begin{array}{l}-0.078 \\
(0.048)\end{array}$ & $\begin{array}{l}-0.091^{*} \\
(0.052)\end{array}$ & $\begin{array}{l}-0.150 \\
(0.107)\end{array}$ & $\begin{array}{l}-0.160 \\
(0.129)\end{array}$ \\
\hline $\begin{array}{l}\text { Electorate's Pref. for Decentralization } \\
(\mathrm{t}-1)\end{array}$ & $\begin{array}{l}-0.017 \\
(0.033)\end{array}$ & $\begin{array}{l}-0.012 \\
(0.043)\end{array}$ & $\begin{array}{c}0.069 \\
(0.072)\end{array}$ & $\begin{array}{c}0.080 \\
(0.176)\end{array}$ \\
\hline Interregional Inequality $(\Delta)$ & & & $\begin{array}{l}1.426 \\
(4.453)\end{array}$ & $\begin{array}{l}-1.844 \\
(7.534)\end{array}$ \\
\hline Interregional Inequality $(\mathrm{t}-1)$ & & & $\begin{array}{c}0.453 \\
(2.195)\end{array}$ & $\begin{array}{l}-0.070 \\
(8.480)\end{array}$ \\
\hline (Log of) GDP per Cap. $(\Delta)$ & & & $\begin{array}{l}1.336 \\
(3.355)\end{array}$ & $\begin{array}{c}1.624 \\
(6.503)\end{array}$ \\
\hline (Log of) GDP per Cap. $(\mathrm{t}-1)$ & & & $\begin{array}{l}-0.334 \\
(0.736)\end{array}$ & $\begin{array}{l}0.487 \\
(1.109)\end{array}$ \\
\hline Ethno-Linguistic Fract. & & $\begin{array}{l}1.258^{* *} \\
(0.601)\end{array}$ & & $\begin{array}{l}2.936 \\
(2.052)\end{array}$ \\
\hline (Log of) Area & & $\begin{array}{l}0.013 \\
(0.069)\end{array}$ & & $\begin{array}{l}0.029 \\
(0.205)\end{array}$ \\
\hline Democracy Indicator & & $\begin{array}{c}0.268 \\
(0.291)\end{array}$ & & $\begin{array}{c}0.762 \\
(1.548)\end{array}$ \\
\hline$\eta$ & & $\begin{array}{l}1.000 \\
(0.000)\end{array}$ & & $\begin{array}{l}1.000 \\
(0.000)\end{array}$ \\
\hline Constant & $\begin{array}{c}0.777^{* * *} \\
(0.275)\end{array}$ & $\begin{array}{l}-2.033 \\
(2.883)\end{array}$ & $\begin{array}{c}3.318 \\
(6.392)\end{array}$ & $\begin{array}{l}-10.972 \\
(11.272)\end{array}$ \\
\hline Country Dummies & Yes & FEVD & Yes & FEVD \\
\hline Year Dummies & Yes & No & Yes & No \\
\hline $\begin{array}{l}\text { Observations } \\
\text { Wald } \chi^{2}(54 / 28)\end{array}$ & $\begin{array}{c}990 \\
175363.55 * * *\end{array}$ & 729 & $\begin{array}{c}304 \\
19969.36 * * *\end{array}$ & 328 \\
\hline $\mathrm{F}(10,704 / 14,302)$ & & $3.53^{* * *}$ & & $2.00^{* *}$ \\
\hline Number of countries & 19 & 17 & 13 & 14 \\
\hline
\end{tabular}

Standard errors in parentheses

${ }^{* * *} \mathrm{p}<0.01,{ }^{* *} \mathrm{p}<0.05,{ }^{*} \mathrm{p}<0.1$ 
Table 4

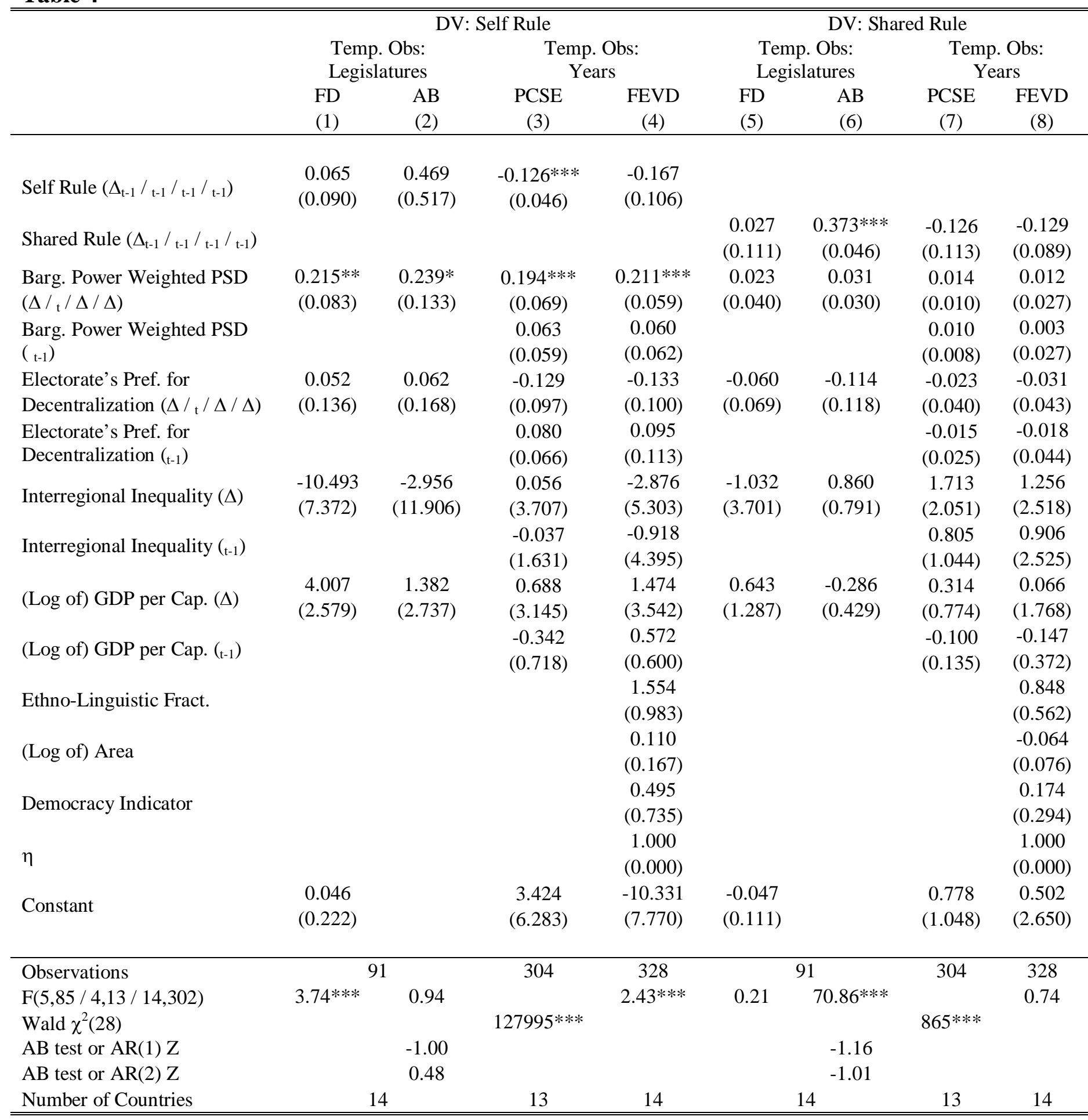

Standard errors in parentheses

*** $\mathrm{p}<0.01,{ }^{* *} \mathrm{p}<0.05,{ }^{*} \mathrm{p}<0.1$ 